\title{
Sacred Excess
}

\section{Organizational Ignorance in an Age of Toxic Data}

\section{Schwarzkopf, Stefan}

Document Version

Accepted author manuscript

Published in:

Organization Studies

DOI:

10.1177/0170840618815527

Publication date:

2020

\section{License}

Unspecified

Citation for published version (APA):

Schwarzkopf, S. (2020). Sacred Excess: Organizational Ignorance in an Age of Toxic Data. Organization Studies, 41(2), 197-217. https://doi.org/10.1177/0170840618815527

Link to publication in CBS Research Portal

\section{General rights}

Copyright and moral rights for the publications made accessible in the public portal are retained by the authors and/or other copyright owners and it is a condition of accessing publications that users recognise and abide by the legal requirements associated with these rights.

Take down policy

If you believe that this document breaches copyright please contact us (research.lib@cbs.dk) providing details, and we will remove access to the work immediately and investigate your claim. 


\section{Sacred Excess: Organizational Ignorance in an Age of Toxic Data}

\section{Stefan Schwarzkopf}

Journal article (Accepted manuscript*)

\section{Please cite this article as:}

Schwarzkopf, S. (२०२०). Sacred Excess: Organizational Ignorance in an Age of Toxic Data. Organization Studies, 41(2), 197-217. https://doi.org/10.1177/0170840618815527

DOl: https://doi.org/10.1177/0170840618815527

Copyright (C) The Author(s) २019. Reprinted by permission of SAGE Publications.

* This version of the article has been accepted for publication and undergone full peer review but has not been through the copyediting, typesetting, pagination and proofreading process, which may lead to differences between this version and the publisher's final version AKA Version of Record.

Uploaded to CBS Research Portal: September २०२० 


\title{
Sacred Excess: Organizational Ignorance in an Age of Toxic Data
}

\author{
Stefan Schwarzkopf
}

\begin{abstract}
Actors in data-intensive industries at times deliberately induce and reproduce organizational ignorance by engaging in over-production of data. This observation leads the paper to make two claims. First, members of these industries fetishize data excess not in order to reduce, but in order to reproduce and stabilize organizational ignorance. Second, in this process of fetishization, organizational ignorance gives rise to forms of collective effervescence similar to that found in totemistic religions. This effervescence allows organizational actors to draw defining lines around that which is marked as awe-inspiring, dangerous and off-limits, namely the sacred. In reviewing organizational ignorance from the perspective of the sacred, this paper proposes that, paradoxically, contemporary forms of data creation allow companies and industries to organize themselves around ignorance as opposed to the promise of knowledge and insight. The paper uses this theoretical proposal in order to outline the contours of an alternative ontology of organizational ignorance, one that understands this phenomenon in terms of excessive presence of data and information.
\end{abstract}

Keywords data, excess, ignorance, paradox, sacred 


\section{Introduction}

This article contributes to research into the nature of social coordination in data-intensive organizational environments. It argues that the global data industry is held together not only by the aim to remove ignorance but, paradoxically, also by reproducing it. Identifying the paradoxical nature of ignorance allows us to improve our understanding of its multiple organizational functions, including its connection to the sphere of the sacred. The article provides evidence that organizational ignorance is reproduced through social mechanisms and discourses that both celebrate data excess and try to contain its polluting impact. Celebration and containment render data overabundance into a fetish, which in turn helps maintain the specific sociality and morality the data industry is based upon. By highlighting the fetish character of data excess and the demonic-totemic quality of ignorance, the article provides the elements of a revised social ontology of organizational ignorance. Within this new framework, scholars will be able to identify two sources of organizational ignorance: firstly, the absence (apousia) of data and information, and secondly the excessive presence (parousia) of data and information. The article argues that the data industry struggles with and discursively mobilizes both sources of organizational ignorance for very strategic reasons.

Ignorance is at once everywhere and nowhere in contemporary studies of economic organization. When discussing ignorance, organization scholars usually theorize the subject in terms of $a$ gnosia ( $\dot{\alpha} \gamma v \omega \sigma i \alpha)$, that is the recognized absence of what is desired, namely knowledge. Thus defined negatively, ignorance ekes out its existence as that which it is not, namely the state of knowing. Classified as permanent signifier of absence, ignorance is mostly talked about when its complement of knowledge is being theorized (Gaudet, 2013; Smithson, 1985; Ungar, 2003). Organization theorists are of course well aware that knowledge is never perfectly attainable, and 
that it comes in a myriad of forms such as dispersed knowledge, tacit and explicit knowledge, and conceptual and empirical knowledge (Gurvitch, 1971, pp. 21-42). Most sociologists of economic organization subscribe to the idea that although ignorance might also come in different forms, such as avoided knowledge and as strategic unknown, it is still engendered by the absence of something (Harvey, Novicevic, Buckley, \& Ferris, 2001; McGoey, 2012a; Roberts, 2013, pp. 227-29).

As an organizational phenomenon in its own right, ignorance is rarely problematized, except when ignorance is the outcome of deliberate cover-ups and confusions, such as in organizational secrecy. Such theorizing of that which is not known however understands ignorance as something to be filled with necessary, appropriate and correct knowledge. This normative view of ignorance understands it in terms of absence, and thus effectively aims at removing ignorance by filling it with something. Whenever this absence is theorized, it is in negative terms, such as ignorance about existing knowledge (known unknown and unknown unknowns), and ignorance arising from the suppression of proper knowledge (taboos, denials, and secrecy). Approaching ignorance through an ontology of absence is the prevalent mode in which the subject is discussed in organizational sociology. For Bakken and Wiik, ignorance is 'knowledge not yet known' and as such clearly inferior to knowledge (Bakken \& Wiik, 2018, pp. 1109 and 1111). Ungar defines the issue as one of 'lack of knowledge or awareness where knowledge exists' (Ungar, 2008, p. 303), and for Roberts and Armitage it is a matter of course that ignorance is a mere 'lack of knowledge or information’ (Roberts \& Armitage, 2008, pp. 335-336).

Defining ignorance in such terms - 'lack', 'not yet' - replicates economistic definitions of nonknowledge as an expression of the pervasive scarcity of data and information (Abbott, 2014). What is missing from an organizational theory point of view is a non-economistic definition of 
the unknown, based in turn on an ontology of presence, not absence. Rather than viewing ignorance from the perspective of what should and will be in its place, I suggest that in particular organizational contexts ignorance actually stems from excessive presence. Ignorance can also emerge because of an overflow of too much data, too much information, and of too many things drawn into the abyss of the unknown because of sheer informational overflow.

Having too many data points at hand and thus 'knowing too much' can have the same debilitating effect on organizational decision-making as too little or no information. Where there is plenty of data, there is plenty of noise, too; and where there is too much noise, organizational actors can end up with an even more intensified feeling of knowing too little, or not quite knowing the right thing yet (Simon, 1971). Data excess can produce new forms of ignorance, such as the inability to create and process information as managers find themselves drowned by more and more incoming data, leading in some cases even to the inability to make decisions or an unwillingness to further engage with more incoming data regardless of their relevance. Davenport and Prusak quote an Arthur Andersen manager who exemplifies how too much can be almost the same as too little: 'We've got so much knowledge (not to mention a lot of data and information, too) in our Knowledge Xchange repository that our consultants can no longer make sense of it' (Davenport \& Prusak, 1998, p. 7). Seen from this angle, organizational ignorance is paradoxical: attempts to remove it through more knowledge creation 'do not automatically lead to a concomitant decrease in non-knowledge’, but all too often to a further increase in ignorance (Kirsch \& Dilley, 2015, p. 24). The paradoxical nature of ignorance as both resulting from glut and abundance as well as scarcity and insufficiency will be exemplified in this paper by studying the many uses of informational overflow in the global data industry, and in market research and opinion polling in particular. 
The article makes a unique contribution to the study of organizations, firstly, by conceptualizing organizational ignorance in relation to the now ubiquitous issue of the unfettered selfreproduction of data (Boellstorff \& Maurer, 2015) and, secondly, by connecting organizational ignorance to the sphere of the sacred. The article proceeds as follows: after presenting the study's theoretical and methodological foundations, it will discuss evidence from an analysis of organizational discourses in the market and opinion research sector. Based on this evidence, the article will provide a process model that outlines how organizational ignorance is an outcome of the paradoxical circularity of excessive data production and the fetishization of this very excess.

\section{Theoretical Foundations}

In order to elicit the meanings and functions of ignorance in the organizational context of dataintensive industries, the article engages with three sets of theories, namely ignorance and agnotology studies, organizational paradoxes, and finally the anthropology of the sacred.

\section{Ignorance and Agnotology Studies}

Ignorance has been conceptualized in a number of theoretically interesting ways, among them in the form of secrecy and that of agnotology (Fernández-Pinto, 2015; Gross, 2012; Gross \& McGoey, 2015; McGoey, 2012b). Drawing on the work of Georg Simmel, Michael and Cynthia Stohl (2011), Chris Grey and Jana Costas (2014), and Martin Parker (2015) have emphasized the role of secrecy as a form of 'organized', intentional non-knowledge. Secrecy creates groups of insiders and outsiders, the latter being excluded from things they could potentially know. Agnotology, in turn, is a way of organizing non-knowledge through the deliberate obfuscation of public policy issues by vested interests. Robert Proctor and others have demonstrated how 
industry-sponsored think tanks and PR consultancies produce floods of conflicting evidence as regards, for example, the health risks of smoking and the environmental side-effects of fracking so as to undermine progressive decision-making. Agnotology is consequently used by large corporations to portray themselves as the exact opposite of being secretive, namely as an active part of the democratic public sphere (Bedford, 2010; Proctor \& Schiebinger, 2008).

The recent wave of theorizations of ignorance has shifted sociological attention from the mere absence of knowledge towards absence itself as an object of analysis. According to Susie Scott, 'paradoxically, nothing is always productive of something', such as new social imaginaries, alternatives and uncertainties (Scott, 2018, p. 3). From an epistemological perspective, the study of absence has emerged as a very productive approach to engage with the way social meaning is created, appropriated and reframed in organizational settings of science and technology (Croissant, 2014; Frickel, 2014; Martin, 2014), the women’s health movement (Tuana, 2006), and the legal system (Feenan, 2007). The present article applies the study of absences to the particular problem of 'ignorance management' (Israilidis, 2013; Cunha, Palma, \& da Costa, 2006; Zack, 1999) in the global data industry in order to surface the kind of visions but also the type of futures that are productive of the discursive order this industry is based on. The paper will produce evidence to show that, like secrets and other organizational concealments, it is not the absence of knowledge per se, but its discursive mobilization as a danger which is generative of creative interactions in the data industries (Courpasson \& Younes, 2018).

\section{Organizational Paradoxes}

Science studies and organization theory today recognize that data-induced ignorance exists as a paradox. Attempting to remove ignorance through the creation of knowledge creates the very 
circumstance for the expansion of ignorance. The more data there are, and the more information we possess of specific issues, the more questions and the more problems are created that require yet more research and data in order to be resolved (Bakken \& Wiik, 2018, p. 1113). According to Donna Haraway, people's knowledge is a function of how and where they look. By producing data in certain ways about certain aspects, other ways of knowing remain unscrutinized. Hence, the production of knowledge is always accompanied by the realization of what is as yet unknown (Gaudet, 2013; Haraway, 1988, pp. 587-90; Law, 2004, pp. 83-85).

The study of paradoxes, and in particular of the paradoxes of the information society, has been afforded a unique place in management and organization studies (Tsoukas, 1997). The mobilization of paradoxes allows organization scholars to escape the confines of internally consistent but unrealistic assumptions about the nature of bureaucratic and economic organizing (Schad, Lewis, Raisch, \& Smith, 2016: 13-14; Poole \& Van de Ven, 1989; Cunha \& Putnam, 2017; Smith et al., 2017; Andriopoulos \& Gotsi, 2017). One of these fateful assumptions is to see contemporary organizations as 'operating mainly through the mobilization of cognitive capacities’ (Alvesson \& Spicer, 2012, p. 1196) which would enable them to successively remove strategic unknowns by gathering more and better data about their environment, their competitors and customers. In the shadow of this assumption, the ignorance paradox has proved to be immensely productive. This article provides evidence for how the paradox of organizational ignorance has helped create an entire industry that promises to relieve managers and policymakers of their ignorance.

Organization scholars know about the paradoxical effect of data over-production and have analyzed the self-reinforcing logic of managerial solutions looking for problems to which they might act as an answer in terms of organizational circularity effects and deviation-amplifying 
feedback loops (Cohen, March, \& Olsen, 1972; Masuch, 1985; Sydow \& Schreyögg, 2013; Tsoukas \& Cunha, 2017). The notion of organizational circularity is important since it alerts scholars also to critical moments of disruption. For example, within knowledge-intensive organizations, socio-technologically induced overflows of data can produce what Linsey McGoey has termed a 'will to ignorance', that is managers' deliberate turning-away from information- and choice-overload so as to remain capable of making decisions (McGoey, 2007; the same in Helland, 2011, and Lange, 2016).

\section{Anthropology of the Sacred}

Anthropological accounts of ignorance, especially in the case of ignorance induced by secrecy, have stressed that lack of knowledge often fosters a deferential attitude towards that which ignorance has rendered absent (High, 2015). Generations of anthropologists have followed Émile Durkheim's insight that something which has been actively put out of reach is often intricately connected to the sacred, namely that which is set apart, closed off, held in special regard, and even forbidden (Durkheim, 2001, pp. 235-42 ). In the case of secrecy and of sacred mysteries, it is the content of secret knowledge which is surrounded by a sense of magic and awe (Luhrmann, 1989, p. 142). Anthropologists of religion however have also argued that it can be the process of ignorance-creation itself which can become sacralized in form of the creation of fetishes. By divorcing an object from its material origins, a fetish is both 'made' and yet derives power from disguising its own material character (Pietz, 1985; Pietz, 1987). In traditional religions, believers are fully aware of the produced, material origins of their fetishes, but they still form 'a cooperative collective’ with their fetishes (Böhme, 2014, p. 66; Latour, 1999). 
This article will apply an anthropological, processual view of fetishization in order to ask to what extent the power of data excess to render positive and certain knowledge unobtainable leads this very excess to become a collectively worshipped entity in its own right. Drawing on anthropological theorizations of the fetish as proposed by Émile Durkheim and Mary Douglas, the article will explore the process through which not data and information per se, but their wasteful, destructive, excessive overflow is being turned into a fetish, similar to the way the consumer research sector fetishizes the image of the sovereign consumer (Arnould \& Cayla, 2015). Since both Durkheim and Douglas reminded us that the worship of fetishes includes their adoration as well as their fear and loathing, the article will provide insights into the way adulation and disgust interplay to reproduce particular orders and discourses associated with organizational ignorance (Douglas, 2002/1966; Durkheim, 2001).

\section{Methodology}

This article relies on organizational discourse analysis and conceptual analysis as key methods to gather and interpret evidence of the enormous productivity of absent knowledge as well as the ambiguous worship of that which is usually believed to remedy this absence, namely copious data. This issue is of importance in an age when the volume of digital data that is created, categorized and sold to third parties is predicted to reach 16 zettabytes by 2020 (Cavanillas, Curry, \& Wahlster, 2016, p. 3). One particular subsection of the global data industry, namely market research and opinion polling, benefits greatly from the promise that more data will ultimately mean better strategy. Market and opinion research was one of the few industries that kept growing throughout the recent financial crisis and ever since. According to ESOMAR, the world association for market, social and opinion research companies, private and public sector 
organizations spend around \$68 Billion each year on survey research, opinion polling and survey analysis worldwide (ESOMAR, 2016, p. 2). In the United States alone, about half a million jobs carry the description of 'market research analyst', and some $\$ 18.5$ Billion are spent on their services, which is twice as much as the country spends on its missile defence system. Some years ago, the US Department of Labor estimated the employment of market research analysts to grow by 32 per cent between 2012 and 2022 (Bureau of Labor Statistics, 2014).

In the process of data collection, texts from industrial magazines, industry publications, blogs and promotional literature, relevant academic journals, practitioner textbooks and monographs were analysed, as well as situated talk in the form of industry meetings and conferences, practitioner interviews and conference speeches. Also included in the analysis was published ethnographic fieldwork based on extensive participant observation and industry surveys conducted within the market research sector, amongst others by Rohit Deshpande and Christine Moorman during the 1980s and 1990s, and more recently by Michael Karesh (2003), Cathrine Grandclement (2011), and Johan Nilsson (2018).

\section{Organizational Discourse}

Organizational discourse analysis has established itself as a method of choice for those interested in the socio-material processes through which social meaning is established and contested within organizations. According to Robert Chia, discourse analysis is 'crucial for a deeper appreciation of the underlying motivational forces shaping the decisional priorities of both organizational theorists and practitioners alike' (Chia, 2000, p. 514). It allows to bring out how 'people's efforts to "make sense" in organizations ... is ordered by a system of absence and presence' (Prichard, Jones, \& Stablein, 2004, p. 229). Following a now widely shared definition of organizational 
discourse as structured collection of texts and other forms of 'talk in organizations' (Oswick \& Richards, 2004), this paper studies how the specific organizational element of 'ignorance' is brought into being and modified through texts and speech acts associated with data, information and knowledge (Grant \& Hardy, 2003; Phillips \& Oswick, 2012, p. 436; Phillips \& Hardy 2002). The main body of texts analysed here emerged from a search for evidence of how actors in the survey research sector problematize the subject of ignorance and data overflow.

In the course of extensive readings of survey industry-related literature, it was surprising to find that relatively little 'talk' was being devoted to ignorance, to not knowing, and to lack of knowledge. This insight was startling since, arguably, the raison d'ettre of the entire sector is to fill up and remove these deficiencies and non-entities. In the process of analyzing industry discourses, it transpired that when the issue of ignorance was brought up, it most often took place in connection with - paradoxically - knowing too much and having too much data. This preliminary insight guided this study in settling for discourse analysis as a method. In other words, a straightforward search for the term 'ignorance' in industrial texts and published speeches would not have yielded insightful results. Since organizational discourses are often characterized by contingent displacements and evasions (Iedema, 2007), discourse analysis helps identify parallel concepts and counter-concepts to that which is organizationally defined as ignorance. Therefore, this study also makes use of methods associated with conceptual analysis (Bothello and Salles-Djelic, 2018, pp. 97-98), thus contributing to the ongoing project of a critical archaeology of ignorance (Feenan, 2007). Exploring ignorance as one of the many 'white spaces of organization' (O’Doherty, de Cock, Rehn, \& Ashcraft, 2013) allows us to observe how this very space becomes circumscribed by norms that are reminiscent of the boundaries between the sacred and the profane. Social groups often create fetishes to both mark and mediate between 
the two sides of such boundaries. The boundaries that signify organizational ignorance and the fetishes that mediate them are created discursively in processes that simultaneously aim at widening and containing the sphere of that which is not known by an organization.

\section{Findings}

The insights generated by the analysis of market research and polling industry discourses suggest that, firstly, this industry acknowledges and even revels in the paradoxical character of ignorance. Secondly, this paradox has strategic uses as the industry portrays increased data creation and better research results as a way out of ignorance. Thirdly, in acknowledging the paradox, some sections within the industry highlight the issue of data overflow as a moral problem. Fourthly, the exalted rejoicing in overflow and its simultaneous moral condemnation leads industry practitioners to treat data excess in terms of the ambiguity of a fetish.

\section{The paradox of ignorance}

Empirical research into the way the specific industries problematize data-induced organizational ignorance reveals that the manager's and the researcher's experience of a causal connection between overflow and ignorance existed since at least the 1950s. These early voices remind us that technology-led data 'explosions', 'floods' and 'deluges' are not at all a new concern for data-based industries but have always been part of a particular discourse pattern. As early as 1951, sociologist David Riesman created a metaphor for this experience by talking for the first time about the notion of 'drowning in data' (Riesman, 1951). At a computer and data conference organized by the American Institute of Electrical Engineers (AIEE) in 1954, an engineer from the US Air Force Flight Test Center coined the term 'data deluge' (Dover, 1954). During the 
1950s and '60s, managers within both public and private sector organizations began to realize that they had become trapped in a paradox, namely that the overflow of data often produced less, rather than more, information, insight and knowledge. At an early Academy of Management meeting, a discussion panel on the 'information explosion' concluded:

The amount and variety of data available to management has increased in the last decade with shocking speed. Historically, this would be considered a cause for joy. Now that the avalanche of data is upon us, with no prospect of abatement, we are not so sure.... Our problem is not too much information, it is too little information. It is ironic that in the midst of a data explosion we encounter an information crisis. By insisting that electronic data processing systems conform to pre-existing information systems and then heaping on masses of new data which an integrated electronic system makes available, management has entangled itself in a growing web of pseudoinformation. (Zand, 1961, p. 44)

Crucially, many commentators argued that yet more powerful computer equipment would provide a way out of the paradox of the 'data explosion’ (Thomas, 1966, p. 810; Anon., 1963, p. 36). By contrast, an executive of Sperry-Rand, the company behind the UNIVAC computers, called the paradox for what it was: 'the paradox of our industry today is that data-processing equipment is turning out too much data and not enough information' (Rowe, 1968).

Excess manifested itself in physical equipment well before the arrival of data warehouses and self-tracking apps. As early as 1948, the then largest global market research company A. C. Nielsen invested nearly half a million Dollars to buy two first-generation Univac computers to help with the statistical processing of market and consumer research data. Ten years later, the US Census Bureau in Suitland, Maryland, bought two such Univac computers through which it sent 
6 million punched cards in the course of a single week, almost each week. During the 'data revolution' of the 1940s and '50s, organizations like the US military, the Federal Reserve Bank and the US Census Bureau produced millions and millions of punched cards each month in order to run their operations. If, hypothetically speaking, the US Census Bureau used 6 million punched cards only every other week, this would have produced 156 million punched cards in a single year (Klapper, 1957; Norberg, 1990). For documentation, these punched cards had to be stored in large warehouses, precursors to today's data centres. During the 1960s, social scientists had to hire trucks to transport tens of thousands of such punched cards when they moved from one research establishment to another (Hauser, 2017, p. 5).

While some sections of the market and opinion survey industry view their own data-producing equipment with suspicion, other sections see in more powerful equipment a way to handle data overload. According to this viewpoint, more data give a better grasp of the information that is needed to solve business-related problems, thus reducing the risk of making wrong decisions (Bradley, 2007, pp. 7-15; Stephens \& Sukumar, 2006). With the rise of data science, data mining and Big Data in the survey sector, this narrative in some ways became more dominant: the larger the data set, the better the answers. Like Wes Nichols, co-founder and CEO of MarketShare, a predictive-analytics company based in Los Angeles, some market researchers place great hope in the efficacy of large data-sets: 'The days of correlating sales data with a few dozen discrete advertising variables are over. Many of the world's biggest companies are now deploying analytics 2.0, a set of capabilities that can chew through terabytes of data and hundreds of variables in real time to reveal how advertising touch points interact dynamically. The results: 10\% to 30\% improvements in marketing performance.' (Nichols, 2013, p. 63 [emphases added]; similar in Erevelles, Fukawa, \& Swayne, 2016). Joining the jubilant choir, the market research 
company GfK's journal Marketing Intelligence Review recently asked: 'Will we observe even more data in the future?' Its response was predictable:

It is very hard to believe that this will not be the case. Devices such as watches, glasses, cameras, technologies like face recognition, thermal imaging, WiFi tracking or beacon communities like WhatsApp, WeChat, and Snapchat will generate even more data.... We now know so much better what consumers do, where they are, what they think, or how they react to the companies' messages. No one predicted 25 years ago how much information we would have available today and what opportunities this data provides. (Skiera, 2016, pp. 15-16; very similar in Chintagunta, Hanssens, \& Hauser, 2016; The Economist, 2017; Verhoef, Kooge, \& Walk, 2016)

The metaphorical language of 'flooding' and 'drowning' in data provides particular affordances, too. Whoever faces a 'data lake' of 'raw and ungoverned' data (Olavsrud, 2017; Weaver, 2016) or being swept away by a data deluge can also choose to immerse themselves in data. In summer 1998, the Belgian Unilever subsidiary Iglo-Ola installed a situation room at its headquarters which allowed senior executives to do just that - by sitting in a business cockpit and be surrounded, on all four walls, by screens that present key business indicators, such as sales figures, the number of new product launches, customer satisfaction rates, market share information, etc., some of them updated daily and weekly. The financial controller in charge of installing this 'corporate war room' presented the acceleration and abundance of data in the cockpit as a solution to that very problem, an abundance of data:

If we look back at the situation before we used the Management Cockpit, it can be characterized from a manager point of view as a situation, where we had an abundance of data but a lack of 
information and knowledge. There was a lot of data available in the company, but nobody knew exactly at which data he had to look at, what was really important. Often data was not linked to other data, it was difficult to retrieve and to interpret. The available management data did not meet the needs of senior and middle management. It was not well prepared for them and not 'digestible'. It contained many contradictions, many versions, too many figures and there was no visual representation. (Daum, 2003, p. 349)

The example of Unilever's 'war room' is not dissimilar in its logic to that of risk exposure in American banks, where hiring Chief Risk Officers (CRO’s) led financial organizations to take on more risk. In the same way, the recent trend of creating roles for Chief Data Officers (CDO’s) has led a lot of firms to refocus their entire world-view around data and to create more of it (Bean, 2018; Pernell, Jung, \& Dobbin, 2017).

\section{The strategic uses of excess}

Excessive data creation has a strategic function within the global market and opinion research industry. While, doubtlessly, most researchers and managers in that industry genuinely aim to solve their clients’ problems, evidence from field work and historical research shows that under certain circumstances the creation of data can adopt the form of an 'performative extravagance' (Chia \& Holt, 2007, pp. 517-21), in which the creation of more and more data does not any longer solve any problems on the side of clients but instead begins to perform conditions that will require yet more data. One example of this is research survey providers developing more data-producing devices in order to make it difficult for new market entrants to get a foothold in the market for research services, a practice known as ‘cramming' (The Economist, 2014). Here, performative extravagance resulting in data overflow becomes a competitive strategy. 
Another example of the strategic uses of excess is researchers and research executives creating an overabundance of data and options in order to cover themselves, their companies and their teams: data overflow here becomes a contingency plan so that subsequent blame for product failure can be averted. Over-abundance, however, does more than deflect criticism: extravagance also pleases clients. During 1950s, for instance, Ford Motor Corporation's advertising agency Foote, Cone \& Belding (FCB) in Chicago was charged with developing a brand name for what was later to become the disastrous 'Ford Edsel'. Eager to indulge their most valuable client, the agency initially came up with a list of 6,000 possible names. A reduced list was then used to run reaction and association tests with consumers and Ford managers in focus group sessions (Mayer, 1958, p. 117). When the Ford company had to choose a name for a new car model a few years earlier, the 'Thunderbird', it was given a list of over 1,000 possible names by the same agency (Lacey, 1986, p. 577; Witzenberg, 1984).

Modern market research methods can develop a pull of sirenic enchantment and lead managers down the path of creating more and larger research projects that help take the mind off more pressing decisions. This happened for instance in the case of Finnish mobile phone producer Nokia, whose researchers in 2006 developed an impressive market segmentation based on a survey of 42,000 consumers in 16 countries. Thus, while the threat of Apple's iPhone was already looming, Nokia followed the magical lure of throwing more data at the problems it perceived (Keller, Apéria, \& Georgson, 2008, pp. 99-100). The global research industry needs to show that it is able to provide solutions to their clients’ problems (Frost, 2012), but it needs these problems, too. The more ignorance and uncertainty there is about people's attitudes and choices as voters and consumers, the more research services are needed. This self-reinforcing logic is known in industry circles as ‘client captivation’ (Nilsson, 2018, pp. 76-77). 
In order to stimulate this logic, market and consumer researchers have not become tired of reminding their clients that the share of new products that fail each year remains at the same constant level, regardless of how 'big’ Big Data are and of how much additional money is being spent on pre-launch research (Castellion \& Markham, 2013; Thompson, 2015). The appropriate response to this paradox is then to spend more money on research. A similarly paraconsistent logic prevails in the opinion polling sector, where a spade of forecasting failures (House of Commons elections in May 2015; EU Referendum in Britain in June 2016; US Presidential elections in November 2016) have raised questions over the efficacy of current prediction models and sampling methods. Trying to recover from these forecasting shocks, market research and polling industry organizations address this problem by calling for the creation of more data about a problem that was caused by data creation (Moncey, 2016; Skibba, 2016).

This logic is remarkably widespread among researchers working in financial, social media and marketing analytics, too, where the strategy is to train algorithms on more and more data and complicate them as data exposure increases. This, in turn, means that the algorithm cannot any longer be fully understood - or known - by a single person precisely because it has become a data behemoth that demands 'feeding'. The most complicated algorithms at work today deny their makers the ability to know precisely how and why an output, such as a decision or a recommendation, is created by the algorithm (Lange, 2016). In his recent work, Carl Miller of the think tank Demos interviewed algorithm developers in the consumer and social media sector. One of his informants exemplifies the logic of data-induced unknowability: 
“There’s a bit of a macho thing about feeding your algorithms as much data as possible,” he said. “The more data you feed it, the better. We work with a lot more data than most teams, actually," he said, drawing his cursor longingly over the script that brought the huge, churning quantities of data that fed the algorithm. Gigabytes, terabytes, petabytes of data were ordered, there on the page.

The researcher knew, of course, what data he'd fed into the process. He knew why he'd designed it, the problem it was trying to solve and the outputs that it produced. However, after he'd been trying to explain it for over an hour, he sat back in his chair, exhausted. "Yes, as you can see, the gap between input and output is difficult to understand," he said.... "From a human perspective you're not sure which of the inputs is significant; it's hard to know what is actually driving the outputs. It's hard to trace back, as a human, to know why a decision was made.” ... The complexity, dynamism, the sheer not-understandability of the algorithm means that there is a middle part between input and output - where it is possible that no one knows exactly what they're doing. (Miller, 2018: pp. 323-26; similar in Gelles, Tabuchi, \& Dolan, 2015; and Smith, 2018)

\section{Excess as moral problem}

Data glut and overabundance also influence the sense of morality that is being shared within the global research industry. Research practitioners are all too aware that data overflow, dressed up as a solution, is in fact a problem. In his 2013 book Consumerology, market researcher Philip Graves acknowledged that there is a fine line between 'useful' research and impression-oriented parading of research 'results’ (Graves, 2013, pp. 121-26; similar in Motti, 2000; Strong, 2015, pp. 48-52). Leading industry representatives in fact bemoan that some of their colleagues frequently produce too much data, and too much data which is then misunderstood as information. In problematizing their approach to data creation, the research industry ultimately emerges as a moral collective. While celebrating their data-creation machinery and ever more sophisticated forms of data overflow, this collective also decries the lack of virtue which these 
practices and technologies reveal. In 2007, the CEO of the Advertising Research Foundation denounced this status quo: 'There is a general belief among researchers that over $50 \%$ of the research done at companies is wasted. They're asked to do things that, even if the research project is perfect, won't be useful. It's covering-your-butt kind of thinking' (Neff, 2007). Hence, there are professionals working within the research sector for whom indulging in data floods has a whiff of impropriety. In other words, generating more data for data's sake is not merely criticized for technical, utilitarian reasons, but on moral grounds.

These moral perturbations are caught up deeply in what Andrew Abbot, Barbara Czarniawska, Orvar Löfgren, Orit Halpern, and others have recognized as organizational problems of excess and overflow (Abbott, 2014; Czarniawska and Löfgren, 2012; Czarniawska and Löfgren, 2014; Halpern, 2015, pp. 61-78). Despite widespread hyperbole, research practitioners accept that producing and then having to cope with an excess of data is at the heart of this industry's predicament. Colin Strong of the research firm GfK Technology warned that the mythological promises of data might make researchers less inclined to critically question their magical and auratic properties: 'There is something very appealing about "data" that convince us that they somehow have an omniscient quality. Data that are generated with the apparent lack of human intervention have an even more magical quality that deters us from questioning them' (Strong, 2014, p. 336). In a widely cited article by Danah Boyd and Kate Crawford, both associated with Microsoft's think-tank Microsoft Research, readers are warned against the 'widespread belief that large data sets offer a higher form of intelligence and knowledge that can generate insights that were previously impossible, with the aura of truth, objectivity and accuracy' (Boyd and Crawford, 2012). In their hearts, industry representatives know that more data create more problems and uncertainties that will only be answered by creating yet more data (Bosch, 2016). 
Underlining the importance of exponential information growth for business strategy, academics and data analysts alike now talk about 'sacred data' (Beath, Becerra-Fernandez, Ross, \& Short, 2012; Watkins \& Molesworth, 2012). In the face of the Big Data-hype, some customer data analysts have also begun to openly address the ‘data fetish' of their peers and told them to stop ‘dreaming of graphs’ (Gomes, 2012; Trivedi, 2011; Woods, 2011).

The industry's own problematization of data as 'fetish', 'sacred', 'magical', 'omniscient', 'auratic' and of 'a higher form' points at the possibility of interpreting the market research sector in terms of a potlatch, that is as highly organized wastefulness, and the industry as a moral community bound together by a fetish. At a potlatch, that is ritualistic feasts celebrated among tribes in the Pacific Ocean and on the Pacific Coast of Canada and the United States, hosts provide an extravagance of food and gifts and often purposefully destroy valuables in front of their guests as a sign of plenty, wealth and generosity. At the next potlatch, guests would then attempt to surpass their hosts' opulence of food display and gift-giving. Crucially, the male host of a potlatch uses the event to parade a totemic item, such as a mask or wooden figurine, in front of tribe members and clansmen, or to pass the object on to his son. The over-production of gifts and the presence of the tribal fetish at the potlatch thus act as means to reconfirm the socialmoral ties that bind tribes and clans together (Coleman, 2004; Vertovec, 1983). As in a potlatch, the research industry perceives the creation of more data as part of a necessary competition to create more loyal clients (captivation). Thus, the extravagance of data excess is misunderstood if interpreted as an unintended and wholly unwelcome side-effect of competition. Rather, as a potlatch, the excess is the structural part that helps create social bonds in the form of stabile dependencies between research providers and their clients. People who are part of potlatches as 
feasts of excess are all-too aware of how the system of extravagance around them works while still experiencing the need of having to play their part in it (Yan, 2005: 254-56).

Waste and excess are not 'useless'; and to say that data have a magic quality for the research industry is not to say that research is make-belief. Taking a closer look at the anthropological underpinnings of waste, we discover the socially highly meaningful functions of that which is in excess. Both deliberate extravagance as well as accidental surplus can be considered waste, and waste can be immensely creative in reproducing the sacred ties that bind collectives, groups and tribes (Douglas, 2002/1966, pp. 9-14, 148-59). In some areas of western Africa, waste heaps function as symbols of sacred kingship and local kings gathered their own household's refuse in front of their abode and demanded villagers to present baskets of rubbish as tokens of allegiance. As these rubbish heaps kept growing into small hills over several generations, sacred monarchy and the waste heap finally merged in the minds of the local population (Guitard, 2017).

\section{The ambiguity of the fetish}

One of the fundamental characteristics of any fetish is its moral ambiguity. Its makers know the fetish is 'made' (Portuguese: feitiço, from Latin factitius, 'artificially made'), and yet feel a sense of loss of control over the fetish as it grows in its power to mediate between sacred and profane (Ellen, 1988, pp. 228-229). In the research service sector, this has led to what Pink, Lanzeni and Horst (2018) have recently identified as ‘data anxiety'. The more financial investment and human effort is devoted to building a global data architecture, the more these data reproduce themselves, and in that process take on a dynamic which is no longer controllable by those who once set out to fashion more and better data. In a recent survey of British senior marketing managers by the Callcredit Information Group, 71 per cent of the surveyed marketers felt 
anxious and overwhelmed by data, and the same number felt it was distracting them from the creative part of their role. Nearly a third of the surveyed stated that they did not have enough time to immerse themselves more fully in the growing data masses they were exposed to (McNicholas, 2016; similar in Abbott, 2001). The opinion polling industry in particular is alarmed by the prospect that the old world of controlled and thus limited data creation through public surveys is swept away by the growth of autonomously self-creating digital data systems. The fear that the overproduction of privately-held data - as opposed to publicly produced and thus controllable survey data - might slowly erase the entire industry was cogently expressed by Robert Groves, Director of the United States Census Bureau:

The Internet and the technologies producing large databases ... have an impact on data about the American public. We're entering a world where data will be the cheapest commodity around, simply because society has created systems that automatically track transactions of all sorts. For example, Internet search engines build data sets with every entry; Twitter generates tweet data continuously; traffic cameras digitally count cars; scanners record purchases; radio frequency identification (RFID) tags feed databases on the movement of packages and equipment; and Internet sites capture and store mouse clicks. Collectively, society is assembling data on massive amounts of its behaviors. Indeed, if you think of these processes as an ecosystem, the ecosystem is self-measuring in increasingly broad scope. ... What has changed in the current era is that the volume of organic data produced as auxiliary to the Internet and other systems now swamps the volume of designed data. In 2004, the monthly traffic on the Internet exceeded 1 exabyte or 1 billion gigabytes. The risk of confusing data with information has grown exponentially. We must collectively figure out the role of organic data in extracting useful information about society. (Groves, 2011, pp. 867-68; similar in Miller, 2017) 
The language of the 'swamp', 'organic' and 'ecosystem' invoked by Groves conjures up an imagery of micro-organisms devouring a once stable infrastructure. Such metaphors, in turn, reflect the ambiguous nature of the sacred as that which is separated, sealed, and warded off. The sacred is not per se good (or bad): what is behind the fence and outside of bounds is glorious, dangerous, untouchable, impure, haram, and thus forbidden (Eliade, 1958, pp. 14-15; Agamben, 2007). Dirt shares the ambivalence of the sacred in that it is seen as potentially transgressing its bounds, infecting the stable order, and thus requiring protection against. Amongst market and opinion researchers, the social reality of the sacred emerges through a new type of language, one that begins to see the practitioner as exposed to 'data smog' (Shenk, 1998), 'infoglut' (Andrejevic, 2013), ‘data pollution’ (Schneier, 2015, p. 238) and 'digital exhaust’ (Nunan and Di Domenico, 2013). Overflowing data masses as 'sacred dirt' (Douglas, 2002/1966, pp. 9-14) engender new strategies to protect the industry against data as a kind of 'toxic asset' (Faitelson, 2018; Schneier, 2016). Supermarket chains like Tesco have for some time regarded their own customers' data as the 'oil of the twenty-first century' (Uwins, 2014). In playful analogy to this idea, practitioners begin to understand sensitive data now also in terms of 'toxic waste' which can overspill, thus needing to be 'scrubbed off' (Towle, 2009; Hannah, 2009).

The ambivalence of the sacred gives data-induced ignorance such potency within the contemporary data industry since it pertains to issues of the perceived efficacy and legitimacy of the entire sector. This efficacy and legitimacy is moderated by the fact that data researchers and their counterparts do not merely form an 'industry' made up of 'providers' and 'clients', but indeed what Durkheim would call a moral collective (Shilling and Mellor, 1998). For example, empirical research into the factors that influence the actual utilization and valuation of market research results among organizations has shown that it is the morally highly laden issue of trust 
between researchers and clients - rather than any inherent 'objective' quality or 'use value' of data themselves - which decides over what data will count as relevant, what information deemed insightful, and what knowledge worth acting upon (Deshpande and Zaltman, 1982; Moorman, Zaltman and Deshpande, 1992; Moorman, Deshpande and Zaltman, 1993; Zaltman and Moorman, 1988). After conducting more than half a year of ethnographic research at General Motors in the early 2000s, Michael Karesh found that it was often, counter-intuitively, product development teams' emphasis on data which prevented them from forming and communicating sufficiently strong product concepts. In teams where interpersonal trust relationships were high and tacit knowledge was accepted, such concepts emerged earlier and moved easier through the stages of product development. According to Karesh, the way product development teams used research results had very little to do with prioritizing an understanding of customers as car buyers and drivers (Karesh, 2003, p. ix). Similar insights into the way practitioners in marketing research use data-based research results creatively in order to stabilize the formation of longterm trust between themselves and their clients were also produced in the recent ethnographic work of Grandclement (2011), Cayla and Arnould (2015), and Nilsson (2018).

As shown above, the attitudes of leading members of the survey industry towards the problem of data excess are characterized by a particular kind of moral ambiguity which combines awe and disgust, worship and fear. According to theologians Rudolf Otto and Paul Tillich, and the sociologist Émile Durkheim, this ambiguity is typical of religious institutions. In religious systems, the moral ambiguity of adoration and dread typically takes the shape of a fetish that turns into a demon. Religions are inherently 'demonic' in that they battle with the danger of turning the sacred into an outward idol, a fetish that becomes feared and worshipped both for its destructive and objectifying properties as well as its creative and innovative potential. According 
to Tillich, the depth of the demonic lies in the fact that in it 'the meaningful and the meaningless elements are inseparably combined' (Otto, 1923; Tillich, 1936, p. 120; Durkheim, 2001, pp. 3049). Collectively speaking, this industry has made ignorance its demon - something to be purged and driven out by the better spirits of more data and more information, and yet also something to be venerated as a creative element that perennially spawns new methodologies, new technologies, new problems and hence new clients and new business models.

\section{Discussion and Interpretation}

This article adds an underexplored perspective to the study of organizational ignorance. Its main contributions are to interpret organizational ignorance in terms of excessive presence rather than absence, and to identify extant elements of sacrality in the discourses of organizational ignorance. Based on an analysis of organizational discourses in the global market research and opinion polling sector, the research findings suggest that there exists an identifiable process by which, firstly, organizational ignorance is recreated and continuously reproduced through data overflow, and secondly, this ignorance is then sacralized through the fetishization of data excess. In this process, ignorance emerges as demonic as it appears to be creative and strategic, and yet also as highly anxiety-inducing. Previous research already highlighted the potential of ignorance as a very central element of sense-making processes within organizations. The findings in this article extend this stream of research in two main ways. Firstly, it was shown that the fetishization of data glut is a strategy that organizations develop, not just in order to cope with the paradox of ignorance, but in order to productively and creatively employ it in order to serve organizational ends. Secondly, the evidence presented above allows us to interpret organizational ignorance in terms of the quasi-religious dimensions of economic organization. Both insights 
clearly signal the need to rethink the ontology of organizational ignorance, a concept which will remain an elusive one as long as it is approached in terms of absence rather than glorified and detested overflow. Changing our perspective in this way would allow us to respond better to the invitation to ignorance which sociologists and anthropologists now frequently invoke (Bakken \& Wiik, 2008; High, Kelly, \& Mair, 2012; McGoey, 2007).

\section{Ontology of organizational ignorance}

The article outlined the contours of an alternative ontology of organizational ignorance which is based on the dialectical relationship between its two causes, namely scarcity and excess. Dataintensive organizations mobilize the excessive presence of data and information (parousia), and at the same time they struggle with agnosia as an absence marked for extinction (apousia). The paradox of organizational ignorance, the fact that accumulating ever more data, information and knowledge actually heightens people's sense of ignorance, hence creating the need to gather yet more data, requires us to acknowledge ignorance as a dialectic process in which absence, lack and dearth can beget an overflowing presence and vice versa. Yet, I also argue that this presence is ill-conceived if it remains at the level of the passive 'throwness' of the individual manager into an inscrutable environment that can only be made sense of by making decisions in the moment (Chia and Holt, 2009, pp. 128, 155-57). Rather, the paradoxical presence that underlies organizational ignorance is one of collectively celebrated glut, waste and excess. Although, as we have seen above, sociologists like Linsey McGoey, Tore Bakken and Joanne Roberts have brought ignorance back into the frame of organizational analysis, they tend to see ignorance as a problem of individual managerial 'decision-making' and 'judgment', and not one of group socialization via a kind of collective sense of awe in which non-knowledge is being held. 
Feasting on ignorance as its demon, the survey industry as a moral collective needs to be interpreted in terms of a very different ontology of the benighted organizational soul. There are already accounts of organizational ignorance that stress the creative potential of such deliberate states of not-knowing, such as Robin Holt and Robert Chia's work on learned ignorance as a form of wisdom (Chia and Holt, 2007). Still, there are quasi-religious elements in the genealogy of ignorance which only partly overlap with the more philosophical traditions of learning how to bear ignorance (Franke, 2015). Rather than coming to terms with ignorance as unavoidable, and thus turning it into a resource for prudent individual decision-making, an anthropological interpretation of ignorance also allows fathoming the possibility of collective effervescence and group-based rapture that surround the continuous, organized production of ignorance. Seen through the eyes of anthropological theories of religious life, ignorance is a demon, a sacred entity both feared and worshipped by a moral collective made up of market researchers and their clients in the great potlatch we know as 'research project'.

Members of this moral collective, as was shown above, largely accept that overflow can result in forms of non-knowledge that are much more than the mere absence of better-quality knowledge/data, but instead of a quasi-sacred nature because of the intense emotional and moral qualities of the anxieties and hopes that are associated with data production about the future (Kennedy \& Hill, 2018). The research industry rallies as a moral community to fashion its own secular version of ignorantia sacra, a kind of 'higher' ignorance that holds out the promise of redemption. Today, everything from media choice, eating disorders and traffic flow problems to issues of democratic engagement, juvenile reoffending patterns, food distribution in the developing world and climate change seems to be a problem solvable by more and more data collection and interpretation (Betancourt, 2013; Morozov, 2013). The enchanted excitement with 
which Big Data, that is excess of data, has been welcomed by a new band of data-management gurus stems from the immense hopes that are created by engaging in excessive data creation (Beer, 2016; Simanowski, 2016, pp. 25-28; Mayer-Schönberger \& Cukier, 2013). Data have become part of a great apparatus of salvation to redeem humanity and save it from selfdestruction through war, resource depletion, greed and political anarchy. The operation of contemporary societies as political-economic systems relies on knowledge, thus ultimately data, on what the consumer-citizenry thinks, what they spend their money on, whom they will vote for, and generally, what their future expectations are. From this craving for knowledge about the future, a secular variety of collective effervescence has emerged that worships the unknown by producing an overflow and excess of data. Like its more reified brother, the secret, ignorance, too, can inspire religious awe (Luhrmann, 1989, pp. 138-39).

Without the recurring reproduction of ignorance, there would be no data industry; and the overflowing splendour of data lakes, clouds and hadoops is the effective, outward form that ignorance as organizational principle has taken on. An alternative conceptual approach to ignorance allows us to see that what organizes the data industry is not necessarily the provision of more and better knowledge, but instead the essential unknowability of the future. Understanding growing data masses not as the remedy for organizational ignorance but as the very cause of its continuous reproduction allows us also to reframe recent debates about 'informational neoliberalism' and the commodification of data in the era of digital capitalism (Neubauer, 2011; Schiller, 1999). An entire critical genre has grown around the idea that the Big Data machinery, in its 'ruthless race toward data profit, toward the financial and productive value of data', ends up producing a 'particular kind of knowledge, one that preferably reaches and covers all consumers constituting this knowledge enterprise. Data/knowledge enables coverage, 
coverage produces power, power produces data credibility, credibility leads to data effectiveness, effectiveness to research funding, funding to data/knowledge, and so on' (Koro-Ljungberg, Cirell, Gong, and Tesar, 2017, pp. 61-62). In this critique of data-based neoliberal capitalism, rent and profit are seen to stem from the exchange value of all the additional and deeper knowledge that is created through the datafication of every move we make as citizens and consumers (Ebeling, 2016; van Dijk, 2014). What this critique misses is that the political economy of the data sector revolves around profuse non-knowledge. It is ignorance, not extant data, which is continuously turned into a profitable position and resold in countless forms of linking and semantically tagging larger and larger sets of unstructured data. The survey research industries are not only filled with data fetishists. A good number of its professionals are acutely aware of the problematic nature of data (over-)production and the tenuous relationship between data and actionable knowledge. And still, in this sector, ignorance has found its most productive organizational form yet. 


\section{References}

Abbott, A. (2013). The problem of excess. Sociological Theory, 32(2): 1-26.

Abbott, J. (2001). Data, data everywhere - and not a byte of use? Qualitative Market Research: An International Journal, 4(3): 182-192.

Agamben, G. (2007). In praise of profanations. In G. Agamben, Profanations (pp. 73-92). New York: Zone Books.

Alvesson, M., \& Spicer, A. (2012). A stupidity-based theory of organizations. Journal of Management Studies, 49(7): 1195-1120.

Andrejevic, M. (2013). Infoglut: how too much information is changing the way we think and know. London: Routledge.

Andriopoulos, C. \& Gotsi, M. (2017). Methods of paradox. In W. Smith, M. Lewis, P. Jarzabkowski, \& A. Langley (Eds.), The Oxford Handbook of Organizational Paradox (pp. 513-527). Oxford: Oxford University Press.

Anon. (1963). The data explosion. The New York Times, October 22: p. 36

Arnould, E., \& Cayla, J. (2015). Consumer fetish: commercial ethnography and the sovereign consumer. Organization Studies, 36(10): 1361-1386.

Bakken, T., \& Wiik, E. L. (2018). Ignorance and organization studies. Organization Studies, 39(8): 1109-1120.

Bean, R. (2018). The Chief Risk Officer dilemma. Forbes Tech Blog, 29 January (https://www.forbes.com/sites/ciocentral/2018/01/29/the-chief-data-officerdilemma/\#32c105fd3896)

Beath, C., Becerra-Fernandez, I., Ross, J., \& Short, J. (20-12). Finding value in the information explosion. MIT Sloan Management Review, 53(4): 18-20. 
Bedford, D. (2010). Agnotology as a teaching tool: learning climate science by studying misinformation. Journal of Geography, 109(4): 159-165.

Beer, D. (2016). The data analytics industry and the promises of real-time knowing: perpetuating and deploying a rationality of speed. Journal of Cultural Economy, 10(1): 21-33.

Betancourt, M. (2016). The critique of digital capitalism: an analysis of the political economy of digital culture and technology. New York: punctum books.

Böhme, H. (2014). Fetishism and culture: a different theory of modernity. Berlin: de Gruyter.

Boellstorff, T., \& Maurer, B. (Eds.) (2015). Data, Now Bigger and Better! Chicago: Chicago University Press.

Bok, S. (1989). Secrets: on the ethics of concealment and revelation. New York: Vintage.

Bosch, V. (2016). Big Data in market research: why more data does not automatically mean better information. GfK Marketing Intelligence Review, 8(2): 57-63.

Bothello, J. \& Salles-Djelic, M. L. (2018). Evolving conceptualizations of organizational environmentalism: a path generation account. Organization Studies, 39(1): 93-119.

Boyd, D., \& Crawford, K. (2012). 'Critical questions for Big Data’. Information, Communication \& Society, 15(5): 662-679.

Bradley, N. (2007). Marketing research: tools and technique. Oxford: Oxford University Press.

Bureau of Labor Statistics. (2014). Market research analysts. In Occupational Outlook Handbook, 2014-2015 Edition. Source: www.bls.gov/ooh/business-and-financial/marketresearch-analysts.htm (retrieved 5 May 2015).

Castellion, G., \& Markham, S. (2013). New product failure rates: influence of argumentum ad populum and self-interest. Journal of Product Innovation Management, 30(5): pp. 976979. 
Cavanillas, J. M., Curry, E. \& Wahlster, W. (2016). The big data value opportunity. In J.M. Cavanillas, E. Curry, \& W. Wahlster (Eds.), New horizons for a data-driven economy (pp. 3-11). Cham: Springer.

Chia, R. (2000). Discourse analysis as organizational analysis. Organization, 7(3): pp. 513-518.

Chia, R., \& Holt, R. (2007). Wisdom as learned ignorance: Integrating East-West perspectives. In E. Kessler, \& J. Bailey (Eds.), Handbook of organizational and managerial wisdom (pp. 505-26). Thousand Oaks, CA: Sage.

Chia R., \& Holt, R. (2009). Strategy without design: The silent efficacy of indirect action. Cambridge: Cambridge University Press.

Chintagunta, P., Hanssens, D., \& Hauser, J. (2016). Marketing science and big data. Marketing Science, 35(3): 341-2.

Clausen, A.R. (1969). Response validity in surveys. Public Opinion Quarterly, 32(4): 588-606.

Cohen, M.D., March, J.G., \& Olsen, J.P. (1972). A garbage can model of organizational choice. Administrative Science Quarterly, 17(1): pp. 1-25.

Coleman, S. (2004). The charismatic gift. Journal of the Royal Anthropological Institute, 10(2): 421-442.

Croissant, J. (2014). Agnotology: ignorance and absence, or towards a sociology of things that aren’t there. Social Epistemology, 28(1): 4-25.

Courpasson, D., \& Younes, D. (2018). Double or quits: understanding the links between secrecy and creativity in a project development process. Organization Studies, 39(2-3): 271-295.

Cunha, M. P., \& Putnam, l. (2017). Paradox theory and the paradox of success. Strategic $\begin{array}{lllll}\text { Organization, } & \text { first } & \text { published } & \text { online: } & \text { October }\end{array}$ (https://doi.org/10.1177/1476127017739536). 
Cunha, M. P., Palma, P., \& da Costa, N. G. (2006). Fear of foresight: knowledge and ignorance in organizational foresight. Futures, 38: 942-955.

Czarniawska, B., \& Löfgren, O. Eds. (2012). Managing Overflow in Affluent Societies. Palgrave: London.

Czarniawska, B., \& Löfgren, O. Eds. (2014). Coping with Excess: how Organizations, Communities and Individuals manage Overflow. Edward Elgar: Cheltenham.

Daum, J. H. (2003). Intangible Assets and Value Creation. Chichester: John Wiley \& Sons.

Davenport, T., \& Prusak, L. (1998). Working Knowledge: How Organizations Manage what They Know. Cambridge, MA: Harvard Business School Press.

Deshpande, R., \& Zaltman, G. (1982). Factors affecting the use of market research information: a path analysis. Journal of Marketing Research, 19(1): 14-31.

Douglas, M. (2002/1966). Purity and danger: An analysis of concepts of pollution and taboo. Abingdon: Routledge.

Dover, J. (1954). A centralized data processing system. In AIEE-IRE '54 (Western) Proceedings of the February 11-12, 1954, Western Computer Conference: trends in computers: automatic control and data processing (pp. 172-183). New York: ACM Publications.

Durkheim, É. (2001). The elementary forms of religious life. Oxford: Oxford University Press.

Ebeling, M. (2016). The uncanny lives of data commodities. In M. Ebeling, Healthcare and big data: Digital spectres and phantom objects (pp. 115-131). New York: Palgrave Macmillan. Eliade, M. (1958). Patterns of Comparative Religion. New York: Sheed \& Ward.

Ellen, R. (1988). Fetishism. Man, 23(2): 213-235.

Erevelles, S., Fukawa, N., \& Swayne, L. (2016). Big Data in consumer analytic and the transformation of marketing. Journal of Business Research, 69: 897-904 
ESOMAR. (2016). Global market research 2016: An ESOMAR industry report. Amsterdam: ESOMAR.

Faitelson, Y. (2018). The rise of toxic data. Forbes Tech Blog, May 22: $\quad$ https://www.forbes.com/sites/forbestechcouncil/2017/05/22/the-rise-of-toxicdata/\#2230d26e2092.

Feenan, D. (2007). Understanding disadvantage partly through an epistemology of ignorance. Social \& Legal Studies, 16(4): 509-531.

Fernández-Pinto, M. (2015). Tensions in agnotology: Normativity in the studies of commercially-driven ignorance. Social Studies of Science, 45(2): 294-315.

Franke, W. (2015). Learned ignorance: The apophatic tradition of cultivating the virtue of unknowing. In M. Gross \& Linsey McGoey (Eds.), Routledge International Handbook of Ignorance Studies (pp. 26-35). London: Routledge.

Frickel, S. (2014). Absences: methodological note about nothing, in particular. Social Epistemology, 28(1): 86-95.

Frost, J. (2012). MRS and the market research industry. (Interview with Jane Frost, CEO of the $\begin{array}{llll}\text { Market } & \text { Research } & \text { Society, } & \text { August }\end{array}$ 2012). https://www.youtube.com/watch?v=Xc1zelhAt2A (accessed 17 March 2017).

Gaudet, J. (2013). It takes two to tango: knowledge mobilization and ignorance mobilization in science research and innovation. Prometheus, 31(3): 169-187.

Gelles, D.; Tabuchi, H., \& Dolan, M. (2015). Weak car software becomes the weak spot under the hood. New York Times. 26 September: p. BU1.

Gomes, L. (2012). Is there big money in big data? MIT Technology Review, May 3. https://www.technologyreview.com/s/427786/is-there-big-money-in-big-data/. 
Grandclement, C. (2011). Convoking the consumer in person: the focus group effect. In D. Zwick \& J. Cayla (Eds.), Inside Marketing: Ideologies, Practices, Devices (pp. 87-114). Oxford : Oxford University Press.

Grant, D., \& Hardy, C. (2003). Introduction: struggles with organizational discourse. Organization Studies, 25(1): 5-13.

Graves, P. (2013). Consumerology: the truth about consumers and the psychology of shopping. London: Nicholas Brealey.

Grey, C., \& Costas, J. (2014). Bringing secrecy into the open: Towards a theorization of the social processes of organizational secrecy. Organization Studies, 35(10): 1423-1447.

Gross, M., \& McGoey, L. (2015). Introduction. In M. Gross \& L. McGoey (Eds.), Routledge International Handbook of Ignorance Studies (pp. 1-14). London: Routledge.

Gross, M. (2010). Ignorance and surprise: science, society and ecological design. Cambridge, MA: MIT Press.

Gross, M. (2015). 'Objective culture’ and the development of nonknowledge: Georg Simmel and the reverse side of knowing. Cultural Sociology, 6(4): 422-437.

Groves, R. (2011). Three eras of survey research. Public Opinion Quarterly, 75(5): 861-871.

Guitard, E. (2017). The sacred king as a waste heap in northern Cameroon. Journal of Material Culture. First published August 4, 2017 (accessed August 13, 2017).

Gurvitch, G. (1971). The social frameworks of knowledge. Oxford: Blackwell.

Halpern, O. (2015). Beautiful data: a history of vision and reason since 1945. Durham, NC: Duke University Press. 
Hannah, J. (2008). New policy will scrub sensitive data from thousands off computers.

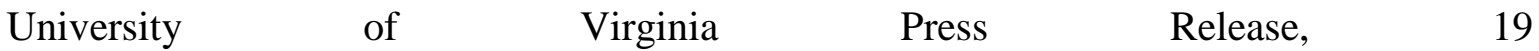
June: www.itc.virginia.edu/security/highlysensitivedata/.

Haraway, D. (1988). 'Situated knowledges: the science question in feminism and the privilege of the partial perspective'. Feminist Studies, 14(3): 575-599.

Harvey, M., Novicevic, M., Buckley, M.R., \& Ferris, G. (2001). A historic perspective on organizational ignorance. Journal of Managerial Psychology, 16(6): 449-468.

Hauser, R. (2017). A life in sociology. Annual Review of Sociology, 43: 1-18.

Helland, P. (2011). If you have too much data, then 'good enough' is good enough. Communications of the ACM, 54(6): 40-47.

High, C., Kelly, A., \& Mair, J. (Eds.) (2012). The anthropology of ignorance: An ethnographic approach. New York: Palgrave Macmillan.

Iedema, R. (2007). On the multi-modality, materiality and contingency of organizational discourse. Organization Studies, 28(6): 931-946.

Israelidis, J. (2013). Ignorance management: an alternative perspective on knowledge management. $\mathrm{PhD}$ thesis, Loughborough University.

Karesh, M. (2003). The cultivation and trust-based application of tacit knowledge within a product development organization. PhD, University of Chicago, Department of Sociology.

Keller, E. F. (1992). Secrets of life, secrets of death: essays on language, gender and science. New York: Routledge.

Keller, K. L., Apéria, T., \& Georgson, M. (2008). Strategic Brand Management: A European Perspective. Harlow: Pearson Education. 
Kennedy, H., \& Hill, R. L. (2018). The feeling of numbers: emotions in everyday engagements with data and their visualizations. Sociology, 52(4): 830-848.

Kirsch, T., \& Dilley, R. (2015). Regimes of ignorance: an introduction. In T. Kirsch \& R. Dilley (Eds.), Regimes of Ignorance: Anthropological Perspectives on the Production and Reproduction of Non-Knowledge (pp. 1-29). New York: Berghahn.

Klapper, J. Ed. (1957). The machine revolution in the processing of data'. Public Opinion Quarterly, 21(3): 410-413.

Koro-Ljungberg, M., Cirell, M.A., Gong, B., \& Tesar, M. (2017). The importance of small form: 'Minor' data and 'BIG' neoliberalism. In N. K. Denzin \& M. D. Giardina (Ed.), Qualitative Inquiry in Neoliberal Times (pp. 59-72). New York: Routledge.

Lacey, R. (1986). Ford: the men and the machine. London: Heinemann.

Lange, A.-C. (2016). Organizational ignorance: an ethnographic study of high-frequency trading. Economy \& Society, 45(2): 230-250.

Latour, B. (1999). The slight surprise of action: fact, fetishes, factishes. In B. Latour, Pandora's hope: essays on the reality of science studies (pp. 266-292). Cambridge, MA: Harvard University Press.

Law, J. (2004). After method: mess in social science research. London: Routledge.

Luhrmann, T.M. (1989). The magic of secrecy. Ethos, 17(2): 131-165.

Marion, J. L. (2002). In excess: studies in saturated phenomena. New York: Fordham University Press.

Martin, B. (2014). Constructing and investigating absences in knowledge. Social Epistemology Review and Reply Collective, 3(5) 73-81. 
Masuch, M. (1985). Vicious circles in organizations. Administrative Science Quarterly, 29(1): $14-33$.

Mayer, M. (1958). Madison Avenue, USA. Penguin: Harmondsworth.

Mayer-Schönberger, V., \& Cukier, K. (2013). Big data: a revolution that will transform how we live, work and think. London: John Murray.

McGoey, L. (2007). On the will to ignorance in bureaucracy. Economy \& Society, 36(2): 212235.

McGoey, L. (2012a). The logic of strategic ignorance. British Journal of Sociology, 63(3): 533576.

McGoey, L. (2012b). Strategic unknowns: Towards a sociology of ignorance. Economy \& Society, 41(1): 1-16.

McNicholas, S. (2016). The Data Dilemma. London: CallCredit, 05 October (https://www.callcredit.co.uk/press-office/news/2016/10/data-dilemma-findings-revealed).

Miller, C. (2018). The Death of the Gods: the New Global Power Grab. London: Heinemann.

Miller, P. V. (2017). Is there a future for surveys? Public Opinion Quarterly, 81(Special Issue): 205-211.

Moncey, P. (2016). Call for papers: challenges in accurately measuring public opinion. http://www.mrs.org.uk/pdf/ijmrcall.pdf (accessed 14 November 2016).

Moorman, C., Deshpande, R. \& Zaltman, G. (1993). Factors affecting trust in market research relationship. Journal of Marketing, 57(1): 81-101.

Moorman, C., Zaltman, G., \& Deshpande, R. (1992). Relationships between providers and users of market research: the dynamics of trust within an between organizations. Journal of Marketing Research, 29(August): 314-328. 
Morozov, E. (2013). To save everything, click here: the folly of technological solutionism. New York: PublicAffairs.

Motti, J. (2000). Customer Tracking: It's Not Just Web-site hits. Information Week, Issue 772, February 7: 104.

Neff, J. (2007). R-E-S-P-E-C-T: Why market research just doesn't get it. Advertising Age, September 24.

Neubauer, R. (2011). Neoliberalism in the information age, or vice versa? Global citizenship, technology, and hegemonic ideology. tripleC, 9(2): 195-230.

Nichols, W. (2013). Advertising analytics 2.0. Harvard Business Review, 91(3): 60-68

Nilsson, J. (2018). Constructing consumer knowledge in market research: an ethnography of epistemics. PhD thesis, Linköping University.

Norberg, A. (1990). High-technology calculation in the early 20th century: Punched card machinery in business and government. Technology and Culture, 31(4): 753-779.

Nunan, D., \& M.L. di Domenico (2013). Market research and the ethics of Big Data. International Journal of Market Research, 55(4): 505-520.

O’Doherty, D., De Cock, C., Rehn, A., \& Ashcraft, K. L. (2013). New sites/sights: exploring the white spaces of organization. Organization Studies, 34: 1427-1444.

Olavsrud, T. (2017). 3 keys to keeping your data lake from becoming a data swamp. CIO Blog, June 8 (https://www.cio.com/article/3199994/big-data/3-keys-to-keep-your-data-lakefrom-becoming-a-data-swamp.html).

Oswick, C., \& Richards, D. (2004). Talk in organizations: local conversations, wider perspectives. Culture and Organization, 10 (2): 107-124. 
Otto, R. (1923). The idea of the holy: an inquiry into the non-rational factor in the idea of the divine and its relation to the rational. London: Humphrey Millford.

Parker, M. (2015). Secret societies: Intimations of organization. Organization Studies, 37(1): 99113.

Pernell, K., Jung, J., \& Dobbin, F. (2017) The hazards of expert control: Chief Risk Officers and risky derivatives. American Sociological Review, 82(3):511-541.

Phillips, N., \& Hardy, C. (2002). Discourse Analysis: Investigating Processes of Social Construction. Newbury Park, CA: Sage.

Phillips, N. \& Oswick, C. (2012). Organizational discourse: domains, debates, and directions. The Academy of Management Annals, 6(1): 435-481.

Pietz, W. (1985). The problem of the fetish, I. RES: Journal of Anthropology and Aesthetics, 9: 5-17.

Pietz, W. (1987). The problem of the fetish, II: The origin of the fetish. RES: Journal of Anthropology and Aesthetics, 13: 23-45.

Pink, S., Lanzeni, D., \& Horst, H. (2018). Data anxieties: finding trust in everyday digital mess. Big Data \& Society, (early online publication: DOI: 10.1177/2053951718756685).

Poli, R. (2017). Introduction to Anticipation Studies. Cham: Springer.

Poole, M., \& Van de Ven, A. (1989). Using paradox to build management and organization theories. Academy of Management Review, 14(4): 562-578.

Prichard, C., Jones, D., \& Stablein, R. (2004). Doing research in organizational discourse: the importance of researcher context. In D. Grant, C. Hardy, C. Oswick, \& L. Putnam (Eds.), The SAGE Handbook of Organizational Discourses (pp. 213-236). London: Sage 
Proctor, R., \& Schiebinger, L. (2008). Agnotology: the Making and Unmaking of Ignorance. Stanford University Press: Stanford, CA.

Riesman, D. (1951). Some observations on social science research. The Antioch Review, 11(3): 259-278.

Roberts, J. (2013). Organizational ignorance: towards a managerial perspective on the unknown. Management Learning, 44(3): 215-236.

Roberts, J., and Armitage, J. (2008). The ignorance economy. Prometheus, 36(4): 335-354.

Rowe, F. A. (1968). Expansion set by Sperry Rand. New York Times, February 25.

Schad, J., Lewis, M., Raisch, S., \& Smith, W. (2016). Paradox research in management science: Looking back to move forward. The Academy of Management Annals, 10(1): 5-64.

Schiller, D. (1999). Digital capitalism: Networking the global market system. Cambridge, MA: MIT Press.

Schneier, B. (2015). Data and Goliath: the hidden battles to collect your data and control your world. New York: Norton \& Company.

Schneier, B. (2016). Data is a toxic asset. CNN Blog, March 1: $\quad$ https://edition.cnn.com/2016/03/01/opinions/data-is-a-toxic-asset-opinionschneier/index.html.

Scott, S. (2018). A sociology of nothing: understanding the unmarked. Sociology, 52(1): 3-19.

Shenk, D. (1998). Data smog: surviving the information glut. San Francisco: Harper.

Shilling, C., and Mellor, P. (1998). Durkheim, morality and modernity: collective effervescence, homo duplex and the sources of moral action. British Journal of Sociology, 49(2): 193-209. 
Simon, H. A. (1971). Designing organizations for an information-rich world. In M. Greenberger (Ed.), Computers, Communications and the Public Interest (pp. 40-41). Baltimore, MD: Johns Hopkins University Press.

Simanowski, R. (2016). Data love: The seduction and betrayal of digital technologies. New York: University of Columbia Press.

Skibba, R. (2016). Why the polls missed Trump. Nature, 539(17 November): 339.

Skiera, B. (2016). Data, data and even more data: Harvesting insights from the data jungle. GfK Marketing Intelligence Review, 8(2): 11-17.

Sloterdijk, P. (2013). In the world interior of capital: Towards a philosophical theory of globalization. London: Polity.

Smith, A. (2018). Franken-Algorithms: the deadly consequences of unpredictable code. The Guardian. August 28.

Smith, W., et al. (2017). Adding complexity to theories of paradox, tensions, and dualities of innovation and change. Organization Studies, 38(3-4): 303-317.

Smithson, M. (1985). Towards a social theory of ignorance. Journal for the Theory of Social Behaviour, 15(2): 151-172.

Stephens, C., \& Sukumar, R. (2006). An introduction to data mining. In Grover, R., \& Vriens, M. (Eds.), The handbook of marketing research: Uses, misuses and future advances (pp. 455-483). Thousand Oaks, CA: Sage.

Stohl, C., \& Stohl, M. (2011). Secret agencies: the communicative constitution of a clandestine organization. Organization Studies, 32(9): 1197-1215.

Strong, C. (2014). The challenge of 'big data': What does it mean for the qualitative research industry? Qualitative Market Research: an International Journal, 17(4): pp. 336-342. 
Strong, C. (2015). Humanizing big data: marketing at the meeting of data, social science and consumer insight. London: Kogan Page.

Sydow, J., \& Schreyögg, G. Eds. (2013). Self-reinforcing processes in and among organizations. Basingstoke: Palgrave Macmillan.

The Economist (2014) Corporate sardines: how incumbent firms pack markets to deter entry. May 3. https://www.economist.com/news/finance-and-economics/21601549-howincumbent-firms-pack-markets-deter-entry-corporate-sardines (accessed 8 March 2018).

The Economist (2017). Fuel of the future: data is giving rise to a new economy. May 6. https://www.economist.com/news/briefing/21721634-how-it-shaping-up-data-givingrise-new-economy (accessed 23 June 2017).

Thomas, E. L. (1966). The physician of the future. Canadian Medical Association Journal, 94(9 April): 808-811.

Thompson, R. (2015). Hidden market forces cause new products to flop. 3 July. $\quad$ http://www.themarketingsite.com/live/article/hidden-market-forces-cause-newproducts-to-flop/40863/.

Tillich, P. (1936). The interpretation of history. New York: Scribner's.

Towle, H. (2009), 'Personal data as toxic waste: a data protection conundrum', Privacy \& Data Security Law Journal, June: 504-520.

Trivedi, A. (2011). What NZ needs is an orgasm? Admedia, 1 November (https://www.highbeam.com/doc/1P2-30223427.html).

Tsoukas, H. (1997). The tyranny of light: the temptations and the paradoxes of the information society. Futures, 29(9): 827-843. 
Tsoukas, H., \& Cunha, M. P. (2017). On organizational circularity: vicious and virtuous cycles in organizing. In W. Smith, M. Lewis, P. Jarzabkowski, \& A. Langley (Eds.), The Oxford Handbook of Organizational Paradox (pp. 393-412). Oxford: Oxford University Press.

Tuana, N. (2006). The speculum of ignorance: the women's health movement and epistemologies of ignorance. Hypatia, 21(3): 1-19.

Ungar, S. (2003). Misplaced metaphor: a critical analysis of the 'Knowledge Society’. Canadian Journal of Sociology, 40(3): 331-347.

Ungar, S. (2008). Ignorance as an under-identified social problem. British Journal of Sociology, 59(2): 301-326.

Uwins, S. (2014). Will customers trust you with their data? Supermarket News, 15 October. $\quad$ http://www.supermarketnews.com/technology/will-customers-trust-you-theirdata.

van Dijck, J. (2014). Datafication, dataism and dataveillance: Big data between scientific paradigm and ideology. Surveillance \& Society, 12(2): 197-208.

Verhoef, P., Kooge, E., \& Walk, N. (2016). Creating value with Big Data analytics: Making smarter marketing decisions. London: Routledge.

Vertovec, S. (1983). Potlatching and the mythic past: A re-evaluation of the traditional Northwest Coast American Indian complex. Religion, 13(4); 323-344.

Weaver, L. (2016). Why companies are jumping into data lakes. Interconnections Equinix Blog, November 10 (https://blog.equinix.com/blog/2016/11/10/why-companies-are-jumpinginto-data-lakes/).

Watkins, R., \& Molesworth, M. (2012). Attachment to digital virtual possessions in videogames. Research in Consumer Behavior, 14: 153-170. 
Witzenburg, G. (1984). The name game. Motor Trend, April: 81-86.

Woods, D. (2011). Curing the big data storage fetish. Forbes, 7 December. htps://www.forbes.com/sites/danwoods/2011/12/07/curing-the-big-datastorage-fetish/\#4c0e84041bb5.

Yan, Y. (2005). The gift and gift economy. In J. Carrier (Ed.), A handbook of economic anthropology (pp. 246-261). Cheltenham: Edward Elgar.

Zack, M.H. (1999) Managing organizational ignorance. Knowledge Directions, 1(Summer): 3649.

Zaltman, G., \& Moorman, C. (1988). The role of personal trust in the use of research. Journal of Advertising Research, 28(5): 16-24.

Zand, D. (1961). The information explosion. Academy of Management Review Proceedings, 1961: 44-46. 